\title{
Socioeconomic Inequality across Religious Groups: Self-Selection or Religion- Induced Human Capital Accumulation? The Case of Egypt ${ }^{1}$
}

\author{
Mohamed Saleh ${ }^{2}$
}

Socioeconomic inequality across religious groups, such as between Protestants and Catholics in Western Europe, Hindus and Muslims in India, Jews and non-Jews in the US and Europe, have been the subject of a voluminous literature in social sciences, and more recently, economics. Perhaps the most well-known explanation of the phenomenon dates back to Max Weber (1905), who traced the Protestant-Catholic socioeconomic gap to Protestantism's culture of work ethic and individualism. Extending his thesis to Asia, Weber hypothesized in a similar vein, that Asiatic religions such as Hinduism and Buddhism were less conducive to Capitalism. The more recent economics of religion literature, while acknowledging the potential endogeneity of religion, attempted to disentangle the causal impact of religious beliefs on socioeconomic outcomes, first in cross-country regressions (Barro and McCleary, 2003), and then in single-country studies (Borooah and Iyer, 2005; Becker and Woessmann, 2009; Chaudhary and Rubin, 2011). A common narrative in the latter line of literature is that some religions put more emphasis than others on the accumulation of human capital.

While the recent economics of religion literature has put socioeconomic inequality across religious groups back to the center of debate in economics, and social sciences more generally, the literature in its attempt to estimate the causal effect of religious beliefs on socioeconomic outcomes, has largely overlooked another (equally) plausible explanation of the phenomenon: that of sorting or self-selection on socioeconomic status (henceforth, SES) into religions. This hypothesis was first put forward by Weber himself when he noted that conversions to Christianity and Islam in India were more concentrated among the lower Hindu castes (Weber, 1958, p. 6). Another example of the selfselection hypothesis is the study by Maristella Botticcini and Zvi Eckstein (2005), who argued that Rabbinic Judaism with its emphasis on literacy to be able to read the Torah and the Talmud drove Rabbinic Jews with a lower taste for education out of Judaism leading the remaining Jews to shrink into a better-off minority. Their thesis seems to combine the two hypotheses. On the one hand, there is self-selection on socioeconomic status into religion, since less educated (likely poorer) Jews systematically converted out of Judaism. On the other hand, there is a causal impact of religious beliefs on the accumulation of human capital, since investment in a child's human capital is driven here by belief in Judaism, and this higher preference for human capital is in turn the primary cause of the positive selection on education of the remaining (non-convert) Jews.

Inspired by the selection conjecture, Saleh (2018) argues that an examination of socioeconomic inequality across religious groups requires a deeper examination of the historical formation process of each group, which may (or may not) have been characterized by self-selection on SES. Indeed, religious groups are not fixed ahistorical categories, but are necessarily formed via a process of conversion of an initial population. The study of socioeconomic inequality between

\footnotetext{
1 This chapter draws extensively on Saleh, Mohamed (2018), "Taxation, Conversions, and the Coptic-Muslim Socioeconomic Gap in Medieval Egypt," Journal of Economic History. I refer the reader to this article for a more complete analysis of the topic. Copyright (C) 2018 The Economic History Association. Used with permission.

2 Toulouse School of Economics and Institute for Advanced Study in Toulouse, 21 Allée de Brienne, Toulouse 31015, France. E-mail: mohamed.saleh@tse-fr.eu.
} 
Copts (Egyptian Christians), who constitute around 6 percent of Egypt's population, and the Muslim majority, is illuminating in this regard. Using a novel data source, two nationally representative individual-level samples from the 1848 and 1868 population censuses that I digitized from the original manuscripts at the National Archives of Egypt (NAE) (Saleh, 2013) and that are among the earliest pre-Colonial censuses from any non-Western country, I documented that Copts were over-represented among white-collar workers (mostly, mid-low bureaucrats) and artisans in 1848 and 1868. Among adult employed men, 50 percent of Copts were white-collar workers and artisans, compared to only 20 percent among Muslims. ${ }^{3}$ This phenomenon is striking if we take into account that Egypt was Coptic Christian before the Arab Conquest of Egypt in 641, and since inand out-migration were limited, Egypt's "Copts" and "Muslims" are both descendants of the pre641 "Coptic" population that either chose to remain Coptic or to convert to Islam. ${ }^{4}$ Bearing this fact in mind, Saleh (2018) argues that Copts' conversion to Islam was characterized by selection on SES due to the tax system. Upon the Conquest, Arabs imposed an annual poll tax on every adult free Coptic male, which was enforced until 1856. As conversion freed Copts from the poll tax liability, and since the conversion incentive was decreasing in income owing to the (quasi) lump-sum feature of the tax, I hypothesize that the tax caused the conversion of poorer Copts, leading Copts to shrink into a better-off minority. Restrictions on apprenticeships and schooling imposed by each religious group led the initial selection to perpetuate thereafter.

There are a few distinguishing features of this hypothesis in comparison to the existing studies that emphasize self-selection in religious conversions. Whereas Weber (1958) did not specify a selection mechanism of converts, selection is caused here by an economic incentive, the tax exemption. This incentive is distinct from the religious incentive to read the Bible in Botticini and Eckstein (2005). And unlike the latter article, the persistence of the Coptic-Muslim SES gap is explained by group restrictions on acquiring skills, in essence a supply-side explanation, and not by Copts' higher preference for human capital (i.e. the demand side), a point that I will come back to later.

The study of taxation, conversions, and the Coptic-Muslim SES inequality contributes to a century-long debate on the Middle East. Inspired by major papyri discoveries from early Islamic Egypt, pioneering early-twentieth-century historians and papyrologists such as Julius Wellhausen (1902), Carl Becker (1902), Harold Bell (1910), and Adolphus Grohmann (1932), emphasized the tax incentive of conversion to Islam under the early Arab Caliphate. The hypothesis of tax-induced conversions triggered fierce debates among historians, however. While scholars such as Gladys Frantz-Murphy (2004) and Yossef Rapoport (2004) endorsed the hypothesis, others such as Daniel Dennett (1950), Kosei Morimoto (1981), and Petra Sijpesteijn (2013) took a cautious stance in light of the growing papyri discoveries that suggested that conversions in Egypt may not have started until the mid-eighth century. A third group argued that conversions occurred even later for other causes including the suppression of Coptic tax revolts in the ninth century (Al-Maqrizi 2002 [1500]; Mikhail 2004) and state persecution in 1250-1517 (El-Leithy 2005), while a fourth group contended that it was Islam's appeal that attracted converts (El-Shayyal 1966). Despite this large body of scholarship, and partially due to data limitations, the "conversion" literature did not address the SES

\footnotetext{
${ }^{3}$ Copts were not a political elite minority though. In 1848-1868 half of Copts were farmers and unskilled workers, and Muslims (mostly Turks) monopolized top political elite positions. The highest white-collar positions that Copts reached were limited to mid-low bureaucracy such as scribes, accountants, and land tax collectors. However, the hypothesis of self-selected conversions seeks to understand why Copts were richer, on average, than Muslims.

${ }^{4}$ Converts could not switch back to Christianity due to the death penalty of apostates in Islam.
} 
advantage of the surviving non-Muslim minorities, a task that was left to a separate body of (qualitative) literature (Tagher 1951; Issawi 1981; Courbage and Fargues 1997), and so the impact of taxation on the inter-religious SES differences in the region has remained a black box. As a result of this omission, neither the regressivity of the poll tax nor the possibility of selection-on-SES of converts, a logical consequence of tax regressivity, was examined by this literature, with the exception of a conjecture by Courbage and Fargues (1997, pp. 22-23). Notice that the argument here is that taxation led to self-selected conversions, and not simply, conversions, as suggested by the early-twentieth-century scholars. This distinguishes taxation from the other causes of conversion that did not necessarily trigger self-selection of converts. In particular, I do not claim that taxation was the sole cause of conversions, but that, compared to the other causes, taxation offers a consistent answer to both conversions and the Coptic-Muslim SES gap.

The long-term trends of the poll tax, Copts' population share, and the Coptic-Muslim SES gap, are broadly consistent with the selection hypothesis. To construct these trends, I draw on novel data sources including a village-level dataset on Christian churches and monasteries in 1200 and 1500, and an individual-level dataset on occupations and religion in 641-969 $(\mathrm{N}=402)$ from Egyptian papyri, in addition to the population census samples from 1848 and 1868. The trends suggest that the higher poll tax rate before 1250 was correlated with a decline in Copts' population share and the emergence of a Coptic-Muslim SES gap as farmers and unskilled Copts were more likely to convert, but that conversions subsided afterwards as the tax rate declined. Since taxes were administered at the local level, the econometric evidence on the hypothesis is based on exploiting the cross-district variation in the average poll tax that is observed in the extant papyrological individual-level poll tax payment records in 641-1100. Tax papyri are subject to certain caveats, however. They survived for only four out of 42 kuras (Egypt's administrative units in 641-1036) that map into 11 out of 76 districts in 1848-1868, all located in the Nile Valley, and most papyri are dated within a range, such as a century, rather than a specific date. There are two outcomes of interest. The first is Copts' population share, which I measure in 1200 and 1500 by the village-level presence of at least one Coptic church or monastery, and in 1848-1868 by the individual-level religious affiliation in the population census samples. The second outcome is the Coptic-Muslim SES (occupational) gap, which I am able to observe at the district level in only 1848-1868, but not before. The findings lend support to the selection hypothesis. I document that compared to Copts in "low-tax" districts, Copts whose origin is in a "high-tax" district are relatively fewer in 1200, 1500, and 1848-1868, but differentially more likely to be artisans and white-collar workers in 1848-1868. Since all districts were (almost) 100 percent Coptic in 641, the findings suggest that high-tax districts witnessed relatively more conversions and a more extensive selection on SES that resulted in a greater Coptic-Muslim SES gap.

The empirical evidence indicates that the initial positive selection of non-convert Copts between 641 and 1200 persisted for over a millennium. I argue that this is likely due to group restrictions on apprenticeships and schooling. As conversions sorted Copts and Muslims on occupations, each group then attempted to exclude the other from the artisanal and white-collar occupations in which it was over-represented, via limiting apprenticeships and schooling within group members. Copts restricted access to skills that were required for jobs in mid-low bureaucracy. While Coptic elementary schools taught arithmetic and geometry in order to train Coptic children for jobs in mid-low bureaucracy, Muslim schools did not provide this training (Heyworth-Dunne 1938, pp. 2-7, 84-92). However, it was primarily apprenticeships, not schools, that trained Coptic children for bureaucratic jobs. In Fatimid Egypt (969-1171), "the persistence of Coptic administrative personnel [was because] the agrarian administration was very complex and not easily 
mastered. In it the Copts played an important role at the local level as well as at the central offices in the capital. . . The administrative knowledge was passed on by the officials in their families when fathers employed their sons, thus maintaining the hold of the family over posts," (Samir 1996, p. 190). In the words of Lord Cromer, the British consul of Egypt in 1883-1908, the Coptic accounting system was "archaic" and "incomprehensible to anyone but themselves" (Tagher 1951, p. 213). Copts used fractions and "ambiguous abbreviations" in accounting based on units of measurement in use in rural Egypt. Group effects on acquiring human capital were not limited to Copts in mid-low bureaucracy though. Copts were legally banned from the judiciary, military, police, and clergy, and these jobs were thus monopolized by Muslims. Muslims were banned from brewing that became a Coptic specialization. The 1848 and 1868 census samples reveal that Copts were overrepresented among jewelers, dyers, carpenters, weavers, and tailors, whereas Muslims were overrepresented among blacksmiths, sawyers, bakers, and butchers. Raymond (1973, pp. 544-51) suggests that the reason for the persistence of this occupational specialization was restricting apprenticeships.

There are other theories that can explain both the emergence and the persistence of Copts' economic advantage over Muslims. I refer the reader to Saleh (2018) for a discussion of these theories, but I highlight a few theories here. A well-known explanation of the socioeconomic advantage of local non-Muslim minorities in the Middle East attributes the phenomenon to the rising European influence in the Ottoman Empire after 1800. Charles Issawi (1981) and Timur Kuran (2004) postulated that the privilege of non-Muslim minorities emerged in the nineteenth century (and not before) because Europeans favored non-Muslims or because non-Muslims adopted European legal structures through the Capitulations system. Under this system, non-Muslims in the Ottoman Empire were permitted to use European laws in conflict resolution, whereas Muslims were obliged to resort to Islamic law. The role of the expansion of European schools in the rise of nonMuslim minorities has also been explored (Salama 1963; Abecassis 2000). But although these theories may indeed account for part of the SES advantage of non-Coptic Christians (such as Levantines, Armenians, Greeks) and Jews and for the (possibly) widening SES gap between Copts and Muslims in Egypt after 1850, it does not fully account for the findings. It does not explain why the Coptic-Muslim SES gap emerged by 969 (as indicated by the papyrological evidence), long before the rise of Europe. Furthermore, the 1848-1868 censuses record the "protégé" status that individuals purchased from European consulates in return for having access to European legal structures. The share of protégés was negligible among Copts in both 1848 and 1868, and was only sizable among non-Coptic Christians and Jews; the two groups constituted only 6 percent of nonMuslims in Egypt and were mostly urban. These differences are likely due to occupational specialization. While non-Coptic Christians and Jews excelled in commerce; a profession that involved transactions with Europeans where access to European laws mattered, Copts' advantage stemmed from artisanship and bureaucracy where European laws had less of an influence.

Nevertheless, even if the emergence of the Coptic-Muslim SES gap can be, at least partially, traced to the initial selection on SES due to, say, the tax system, the persistence of inequality can still be attributed to other factors. These include, most importantly, the intergenerational transmission of inter-group cultural differences that are caused by differences in religious beliefs. For example, one can hypothesize, following Botticini and Eckstein (2005), that Coptic Christianity, like Rabbinic Judaism, encouraged the accumulation of human capital which pushed Copts with a lower preference for education to convert to Islam. And even if self-selected conversions were triggered by the tax system, one can still argue that Coptic Christianity encouraged human capital accumulation once non-convert Copts shrank into a minority. This theory is unlikely to hold though as there is no 
literacy requirement under Coptic Christianity and illiteracy among adult male Copts in 1986 was 34 percent. Furthermore, Coptic schools were purely religious in 641 when conversions started and their shift towards teaching secular subjects by 1700 was possibly a result of selected conversions on SES. Another cultural explanation is hypothesized, inspired by Weber (1905), that Copts had a stronger work ethic. Yet, Coptic Christianity shared with the Egyptian Muslim Sufi culture a mystical outlook on life that attributed materialistic success to metaphysical factors rather than to hard work. Moreover, the fact that Copts' advantage stemmed from bureaucracy and artisanship, and not from commerce, indicates that Coptic Christianity was not more conducive to Capitalism than Islam.

This is not to say that there were no other historical processes, besides group restrictions on skills, that affected the Coptic-Muslim SES gap, however. To be sure, state policies throughout Egypt's history and European influence starting from 1800 had their effects. For example, the Coptic-Muslim differences in human capital were altered in favor of Copts with state industrialization in the nineteenth century and with the expansion of European schooling after 1850, and then in favor of Muslims, with the introduction of public mass education a century later in 1951-1953.

Saleh (2015) examines the impact of nineteenth-century Egypt's state industrialization on the Coptic-Muslim occupational differences. Muhammad Ali Pasha, the autonomous Ottoman viceroy of Egypt, and his successors, led an ambitious state industrialization program that occurred in two waves in 1816-1848 (mostly, textiles) and 1848-1868 (mostly, transportation). Although the program did not produce economic development in the sense of rapid sustainable growth in GDP per capita, it triggered a social transformation. In 1848, state firms employed eight percent of the adult active male urban population and in 1868 three percent, forming the nucleus of the Egyptian working class. But did state industrialization act as a "melting pot," reducing occupational inequality between Copts and Muslims? Using the 1848 and 1868 population census samples, I argue that it did not. In 1848 state firms had relatively fewer medium-skilled Muslim and Christian workers than the traditional sector, with a stronger effect on Christians in urban Egypt. For Muslims the effect was compounded by a drop in the likelihood of being a high-skilled worker, resulting in a "de-skilling" effect on Muslims. For Christians, the dearth of medium skill jobs in state firms was offset by a rise in the likelihood of being a high-skilled worker, perhaps to fill in the administrative jobs in state firms, resulting in an "up-skilling" effect on Christians. In contrast, state industrialization in 1868 (equally) decreased the likelihood of being a low-skilled worker among both Muslims and Christians, resulting in an "up-skilling" effect on both groups. But while the "up-skilling" of Muslims was came from an increase in the likelihood of being a medium-skilled worker and the likelihood of being a high-skilled worker, the "up-skilling" of Christians was solely due to an increase in the likelihood of being a high-skilled worker, which was greater than the corresponding increase among Muslims.

The introduction of modern education, whether public or foreign, after 1800, did not reduce inequality either. Up to 1848, the vast majority of students, whether Muslims or Copts, were enrolled in elementary religious schools (kuttabs) or higher religious institutions such as al-Azhar. A tiny percentage of Muslim students were enrolled in modern public schools that were introduced by Ali in 1818 following the European school model. But although Coptic students were not allowed to enter public schools until 1873, these schools did not push Muslim student enrollment rate up to converge with that of Copts, because it targeted a tiny Muslim population. More importantly, Copts were much faster than Muslims in switching from religious to modern schools. In 1868, 40 percent of Coptic students were already enrolled in modern schools, compared to only 4 percent among Muslim students. But unlike Muslim students who enrolled in public schools, Coptic students in 
modern schools were all enrolled in private schools, both Coptic and foreign (French, American, and English). And by 1907/1908, almost all Coptic students were enrolled in modern schools. By contrast, as late as in 1948/1949, 70 percent of Muslim students were still enrolled in "elementary" (awwaliya) schools (a modernized version of the kuttabs that was created in 1916).

Saleh (2016) examines the effect on the Coptic-Muslim educational and occupational inequality of the expansion of public mass modern education in the 1950s. After a military coup that overthrew the rule of Muhammad Ali's dynasty in 1952 and ended the de facto British Colonization in 1956, Egypt embarked on a pioneering state-led development program in the region. In the educational arena, the post-1952 regime expanded on the public mass education policies that were first introduced by Taha Hussein, a prominent liberal intellectual and Egypt's minister of Education from 1950 to 1952. In 1951-1953, as the final stroke in a century-long process of unifying the dichotomous traditional and modern educational systems, the government transformed traditional "elementary" (awwaliya) schools, into public modern "primary" (ibtida'iya) schools (Boktor 1963, pp. 27-28). Prior to the reform modern primary schools were de facto the sole route to secondary schools, university education, and white-collar jobs, whereas awwaliya schools qualified their graduates to only religious (Muslim or Christian) higher education institutes (Boktor 1936, p. 123; Harby and El-Azzawi 1960). Although the reform entailed partial improvement of equipment and facilities in awwaliya schools to match those in primary schools and the construction of new primary, preparatory, and secondary schools, these measures were limited in scope. Similarly, the reform barely altered the curriculum in awwaliya schools, which almost converged to that of primary schools by 1949. Instead, the reform essentially meant the "re-labeling" of awwaliya schools as public modern primary schools, loosening the entry requirements to post-primary education, and increasing class size in primary, preparatory, and secondary schools in order to absorb the surge in student enrollment. In addition to these policies, as documented by Ragui Assaad (1997), the government abolished tuition fees in public universities in 1961 and introduced in 1961-1964 an employment guarantee in the government and public sectors for graduates of secondary schools and universities, a policy that lasted until the 1983 graduates. As a result of these policies, the supply of modern schools (per 1,000 population of age 5 to 19) more than doubled from 0.44 in 1951/52 to 0.96 in 1959/60, and primary enrollment rose from 1 million students in 1952 to nearly 3.5 million in 1965/66, and preparatory and secondary enrollment expanded even faster, multiplying six fold and threefold respectively, from 1956 to 1961.

Using the 1986, 1996, and 2006 individual-level population census samples that are available on IPUMS-International and the decennial village/quarter-level 1897-1986 population censuses that are available on CEDEJ (2003), I first documented that the Christian-Muslim differences in educational and occupational attainment fell during the second half of the twentieth century. I then exploited the variation across cohorts and districts of birth in the intensity of the reform, by matching two novel data sources: the individual-level 10-percent 1986 population census sample and the district-level 1951/52 school census. I found that the 1951-1953 reform had a positive impact on Muslims' educational and occupational attainment, but had no statistically significant impact on Christians. However, the estimated impacts of the reform on the Christian-Muslim differences with respect to these outcomes are imprecisely estimated and statistically insignificant.

To conclude, self-selected conversions that were induced by the tax system are arguably a plausible explanation of the Coptic-Muslim socioeconomic inequality that emerged in early medieval Egypt. And while group restrictions on white-collar and artisanal skills contributed to the perpetuation of inequality for over a millennium, state policies in industrialization and the growth of 
modern education in 1800-1950 altered the Coptic-Muslim SES gap in favor of Copts. It was not until the arrival of public mass education in the 1950s that the gap declined. It may be tempting to generalize this argument to other parts of the whole Arab World with sizeable non-Muslim minorities (Iraq and the Levant in particular), since the poll tax on non-Muslims was imposed throughout the entire Arab Caliphate, and in fact, in all Muslim-ruled territories. However, I refrain from generalizing the hypothesis beyond Egypt at this stage, since we still know very little about the formation processes of other non-Muslim minorities in the region, such as Greeks, Armenians, Karaite Jews, Rabbinic Jews, and Levantine Christians. There are unexplored data sources that can help to explore this research question including papyri (98 percent of which are still unpublished), the sixteenth-century Ottoman tax registers, and the Ottoman population censuses in 1891-1914. These sources may reshape our understanding of non-Muslim minorities in the region. Understanding the origins of Copts' privilege over Muslims in Egypt is valuable though because Copts are the largest non-Muslim minority (in absolute number) in the region, because unlike other non-Muslims who were mostly urban traders, Copts' spatial and occupational distributions exhibited enough variation to test the selection hypothesis, and because using the medieval papyri advances our knowledge of this phenomenon instead of relying on often subjective narratives.

\section{References:}

Abecassis, Frédéric. "L'enseignement étranger en Egypte et les élites locales 1920-1960: Francophonie et identités nationales.” Ph.D. diss., Université d'Aix-Marseille I, Marseille, 2000.

Assaad, Ragui. "The Effects of Public Sector Hiring and Compensation Policies on the Egyptian Labor Market.” World Bank Economic Review 11, no. 1 (1997): 85-118.

Al-Maqrizi. Al-mawa'iz, wal i'tibar fi zhiker al-khitat wal athar (Sermons and Considerations in Examining Plans and Monuments), Volume 4.1. London: al-Furqan Islamic Heritage Foundation. A. F. Sayyid (Ed.), 2002 [1500].

Barro, Robert J., and Rachel M. McCleary. "Religion and Economic Growth across Countries." American Sociological Review 68, no. 5 (2003): 760-81.

Becker, Carl H. Beiträge zur Geschichte Ägyptens unter dem Islam. Strasbourg: Verlag Von Karl J. Trübner, 1902.

Becker, Sasha O., and Ludger Woessmann. "Was Weber Wrong? A Human Capital Theory of Protestant Economic History." Quarterly Journal of Economics 124, no. 2 (2009): 531-96.

Bell, Harold I. Greek Papyri in the British Museum: Catalogue with Texts, Vol. IV. The Aphrodito Papyri. London, 1910.

Boktor, Amir. School and Society in the Valley of the Nile. Cairo: Elias' Modern Press, 1936.

- The Development and Expansion of Education in the United Arab Republic. Cairo: The American University in Cairo Press, 1963. 
Borooah, Vani, and Sriya Iyer. "Vidya, Veda, and Varna: The Influence of Religion and Caste on Education in Rural India." Journal of Development Studies 41, (2005): 1369-404.

Botticini, Maristella, and Zvi Eckstein. "Jewish Occupational Selection: Education, Restrictions, or Minorities?” Journal of Economic History 65, no. 4 (2005): 922-48.

Centre d'Etudes et de Documentation Economiques, Juridiques, et Sociales (CEDEJ). Century Census CD-ROM: Egypt 1882- 1996. Cairo: CEDEJ, 2003.

Chaudhary, Latika, and Jared Rubin. "Reading, Writing, and Religion: Institutions and Human Capital Formation.” Journal of Comparative Economics 39, no. 1 (2011): 17-33.

Courbage, Youssef, and Philippe Fargues. Christians and Jews under Islam. London-New York: I. B. Tauris Publishers. J. Mabro (Tr.), 1997.

Dennett, Daniel C. Conversion and the Poll Tax in Early Islam. Cambridge, MA: Harvard University Press, 1950.

El-Leithy, Tamer. "Coptic Culture and Conversion in Medieval Cairo 1293-1524 AD.” Ph.D. diss., Princeton University, Princeton, 2005.

El-Shayyal, Gamal. Tarikh misr al-islamiya (History of Islamic Egypt). Cairo: Dar Al-Ma'arif, 1966.

Frantz-Murphy, Gladys. "Conversion in Early Islamic Egypt: The Economic Factor." In Muslims and Others in Early Islamic Society, edited by Lawrence Conrad, 323-30. Burlington, VA: Ashgate, 2004.

Grohmann, Adolphus. “Aperçu de Papyrologie Arabe.” Etudes de papyrologie 1 (1932): 23-95.

Heyworth-Dunne, James. An Introduction to the History of Education in Modern Egypt. London: Luzac and Co., 1938.

Harby, Mohammed Khayri and El-Sayyed Mohammed El-Azzawi. Education in Egypt (U.A.R) in the 20th Century. Cairo: Ministry of Education: Education Documentation Centre of U.A.R., 1960.

Issawi, Charles. The Arab World's Legacy. Princeton: The Darwin Press, 1981.

Kuran, Timur. "The Economic Ascent of the Middle East's Religious Minorities: The Role of Islamic Legal Pluralism.” Journal of Legal Studies 33 (2004): 475-515.

Mikhail, Maged S. A. "Egypt from Late Antiquity to Early Islam: Copts, Melkites, and Muslims Shaping a New Society.” Ph.D. diss., University of California Los Angeles, Los Angeles, 2004.

Morimoto, Kosei. The Fiscal Administration of Egypt in the Early Islamic Period. Kyoto: Dohosha, 1981.

Rapoport, Yossef. "Invisible Peasants, Marauding Nomads: Taxation, Tribalism and Revolt in Mamluk Egypt.” Mamluk Studies Review 8, no. 2 (2004): 1-22. 
Raymond, André. Artisans et Commerçants au Caire au XVIIIe Siècle. Damascus: Institut Français de Damas, 1973.

Salama, Girgis. Tarikh al-Ta'lim al-ajnabi fi misr fil qarnayn al-tasi' 'ashar wal 'ishreen (History of Foreign Education in Egypt in the Nineteenth and Twentieth Centuries). Cairo: Supreme Council for Art, Literature, and Social Sciences, 1963.

Saleh, Mohamed. "A Pre-Colonial Population Brought to Light: Digitization of the Nineteenth Century Egyptian Censuses," Historical Methods: A Journal of Quantitative and Interdisciplinary History, 46.1 (2013), 5-18.

- "The Reluctant Transformation: State Industrialization, Religion, and Human Capital in Nineteenth-Century Egypt.” Journal of Economic History 75, no. 1 (2015): 65-94.

- "Public Mass Modern Education, Religion, and Human Capital in Twentieth-Century Egypt." Journal of Economic History 76, no. 3 (2016): 697-735.

. "On the Road to Heaven: Taxation, Conversions, and the Coptic-Muslim Socioeconomic Gap in Medieval Egypt," Journal of Economic History 78, no. 2 (2018): 394-434.

Samir, Samir Khalil. "The Role of Christians in the Fatimid Government Services of Egypt to the Reign of Al-Hafiz.” Medieval Encounters 2, no. 3 (1996): 177- 99.

Sijpesteijn, Petra M. Shaping a Muslim State: The World of a Mid-Eighth-Century Egyptian Official. Oxford: Oxford University Press, 2013.

Tagher, Jacques. Christians in Muslim Egypt: A Historical Study of the Relations between Copts and Muslims from 640 to 1922. Altenberge: Oros Verlage, 1998 [1951].

Weber, Max. The Protestant Ethic and the Spirit of Capitalism. New York-London: Charles Scribner's Sons, George Allen and Unwin Ltd. T. Parsons (Tr.), 1930 [1905].

- The Religion of India: The Sociology of Hinduism and Buddhism. New Delhi: Munshiram Manoharlal Publishers. H. Gerth and D. Martindale (Trs.), 1996 [1958].

Wellhausen, Julius. The Arab Kingdom and its Fall. Calcutta: University of Calcutta. M. G. Weir (Tr.), 1927 [1902]. 